\title{
PROMOSI KESEHATAN HIV-AIDS DAN STIGMA TERHADAP PENGGUNA NARKOBA SUNTIK (PENASUN) DI KABUPATEN SUMEDANG
}

\author{
Evie Ariadne Shinta Dewi dan Suwandi Sumartias \\ Fakultas Ilmu Komunikasi, Universitas Padjadjaran \\ Email:evie@unpad.ac.id
}

\begin{abstract}
ABSTRAK. Tujuan penelitian ini adalah: 1) untuk memperoleh gambaran tentang pelaksanaan kegiatan promosi kesehatan penanggulangan HIV-AIDS oleh KPA Kabupaten Sumedang 2) tentang makna stigma bagi Penasun dan 3) untuk mengetahui makna promosi kesehatan dalam menghapuskan stigma bagi Penasun. Metode penelitian adalah kualitatif deskriptif dengan pendekatan Studi Kasus, serta teknik pengumpulan data melalui: a) wawancara mendalam (indepth Interview), b) observasi, c) studi pustaka, dan d) focus group discussion. Hasil Penelitian menunjukkan Komisi Penanggulangan AIDS (KPA) Kabupaten Sumedang melaksanakan kegiatan promosi kesehatan sebagai upaya pencegahan penularan HIV-AIDS menggunakan beberapa strategi secara simultan untuk sasaran yang berbeda. Di sisi lain, Penasun memaknai stigma secara positif dan negatif. Makna negatif melahirkan sikap menarik diri dari kehidupan sosial, masa bodoh, apatis, tidak peduli dan putus asa dalam menjalani sisa hidupnya, sedangkan makna postif justru memberikan sisa hidupnya untuk dapat berkontribusi di masyarakat dengan ikut menyampaikan informasi tentang bahayanya HIV-AIDS. Penasun juga memaknai kegiatan promosi kesehatan yang dilakukan KPA Sumedang dalam tiga kategori, yaitu bagus untuk ranah kognitif, cukup untuk ranah afeksi dan masih kurang untuk ranah konasi.
\end{abstract}

Kata kunci: Stigma, Penasun, HIV-AIDS, Promosi Kesehatan.

\section{HIV-AIDS HEALTH PROMOTION PROGRAMME AND STIGMA OF INJECTION DRUG USERS (IDU) IN SUMEDANG}

\begin{abstract}
The aim of this study were: 1) to obtain an overview of the implementation of health promotion activities for HIVAIDS by KPA Sumedang District 2) to obtain in-depth description of the meaning of stigma for IDUs and 3) to determine the meaning of the health promotion in eliminating stigma for IDUs. Result of the sudy showed that AIDS Commission Sumedang District doing health promotion using multiple strategies simultaneously to different targets. At the other hands the Injecting Drug Users defines stigma positively and negatively. Negative meaning such as avoiding social life, indifferent, apathetic, uncaring and despair in live while positif meaning make senses to the rest of his life to be able to contribute to society by contributing to convey information about the dangers of HIV-AIDS. The last finding of the research that IDU interpreted health promotion activities conducted KPA Sumedang in three categories, namely good for cognitive realm, the realm enough for affection and still less to the realm konasi.
\end{abstract}

Key words: Stigma, IDU, HIV-AIDS, Health Promotion.

\section{PENDAHULUAN}

Sejak ditemukan kasus pertama di Bali pada tahun 1987, epidemi AIDS di Indonesia dalam periode kurang lebih 27 tahun menunjukkan kecenderungan kenaikan yang luar biasa bahkan pada beberapa daerah berdampak pada angka kesakitan dan kematian yang terus meningkat.

Persentase kasus HIV tertinggi dilaporkan pada kelompok umur 25 - 49 tahun (73,7\%), diikuti kelompok umur 20-24 tahun $(15,0 \%)$ dan kelompok umur $>50$ tahun (4,5\%). Rasio kasus HIV antara laki-laki dan perempuan adalah 1:1. Hal ini berarti, kasus HIV paling tinggi justru menimpa masyarakat kelompok umur produktif baik laki-laki maupun perempuan. ${ }^{1}$

Terkait penggunaan jarum suntik, buku Pedoman Pencegahan Penularan HIV-AIDS dan IMS bagi

\footnotetext{
Hasil Survei terhadap Pelajar Mahasiswa tahun 2011, Departemen Kesehatan RI
}

Kabupaten/ Kota ${ }^{2}$, menyatakan bahwa pengurangan dampak buruk Napza mulai menjadi perhatian di Indonesia pada tahun 1999. Pada saat itu data epidemi HIV/AIDS bergeser dari penularan melalui hubungan seksual ke penularan melalui penggunaan jarum suntik yang tidak steril secara bergantian/bersama pada kelompok Penasun. Jarum suntik dan peralatan yang berkaitan dengan penyuntikan yang digunakan tidak sekali pakai dan atau digunakan secara bergantian, serta perilaku penyuntikan Napza merupakan jalan yang sangat efektif penularan HIV. Di dunia pada saat ini, dihitung secara kumulatif, diperkirakan terdapat sekitar 2-3 juta Penasun yang terinfeksi HIV. Lebih dari 110 negara telah melaporkan adanya epidemi HIV yang berkaitan dengan pengunaan Napza dengan cara suntik. Kegiatan promosi kesehatan bagi kaum Penasun oleh Pemerintah Kabupaten Sumedang telah dilakukan antara lain melalui program substitusi jarum suntik

\footnotetext{
Diterbitkan oleh Direktorat Jenderal Pengendalian Penyakit dan Penyehatan Lingkungan 2010
} 
dan terapi rumatan Metadon. Namun demikian, seperti dikemukakan oleh pengurus KPA Sumedang ${ }^{3}$, program ini hanya bisa menahan tidak munculnya kasus baru penularan HIV-AIDS, tetapi tidak mengurangi jumlah Penasun di Jatinangor. Salah satu masalah yang dihadapi Penasun adalah adanya stigma dari masyarakat yang membuat mayoritas kaum Penasun memilih untuk mengisolasi diri dari kehidupan sosial dan hanya bergaul dengan sesama Penasun lagi. Peneliti mencermati dengan adanya stigma ini maka partispasi kaum Penasun dalam kehidupan sosial di masyarakatnya akan terhambat dan hal ini bisa saja melahirkan penyakit sosial yang lebih berat dari penggunaan narkoba suntik bahkan bisa menghambat upaya penanggulangan penularan penyakit HIV-AIDS.

Topik stigma karena penyakit HIV-AIDS, sudah banyak diteliti terutama di negara-negara yang angka populasi HIV-AIDSnya cukup tinggi seperti di Afrika. Salah satunya adalah penelitian yang dilakukan oleh Taddese Allemu (2013) yang didiseminasikan dalam jurnal internasional Sahara.

Taddese Alemu, Sibhatu Biadgilign , Kebede Deribe \& Horacio Ruiseñor Escudero ${ }^{4}$ menyatakan beberapa bukti ilmiah menunjukkan bahwa stigma yang terkait dengan HIV / AIDS memiliki efek negatif terhadap keputusan seseorang untuk menjalani tes HIV, untuk mendapatkan pelayanan kesehatan yang memadai dan pada proporsi ODHA yang mengungkapkan status HIV mereka ke pasangan seks (Golin, Isasi, Bontempi \& Eng 2002; Herek, Mitnick, Burris, Chesney, Devine, Fullilove, et al. 1998; Kalichman dan Nachimson 1999; Wolitski, Rietmeijer, Goldbaum \& Wilson 1998).

Stigma dan diskriminasi merupakan hambatan utama dalam pemberian perawatan pada ODHA (Constance A Carrino 2005). Stigma dan diskriminasi terkait HIV telah memicu transmisi HIV, menciptakan hambatan utama untuk mencegah lebih lanjut infeksi dan pengendalian epidemi, untuk meringankan dampaknya dan untuk penyediaan perawatan, dukungan dan pengobatan yang memadai (UNAIDS 2005).

Mencermati hal ini, membangun komunikasi efektif melalui kegiatan promosi Kesehatan pada Penasun di wilayah heterogen dan multikultur seperti Jatinangor tentu bukan pekerjaan mudah bagi Pemerintah Kabupaten Sumedang. Itu sebabnya penelitian ini dirumuskan sebagai berikut: bagaimana peran kegiatan promosi kesehatan oleh komisi penanggulangan AIDS (KPA) kabupaten Sumedang dalam menghapus stigma terhadap pengguna narkoba suntik (penasun)?.

\footnotetext{
${ }^{3}$ Wawancara dengan Tita, staf KPA Sumedang, September 2014.

4 Dalam riset mereka yang berjudul : Experience of stigma and discrimination and the implications for healthcare seeking behavior among people living with HIV/AIDS in resource-limited setting, SAHARA-J: Journal of Social Aspects of HIV/AIDS: An Open Access Journal, downloaded by: [197.156.119.11] On: 25 July 2013, At: 09:05 Publisher: Routledge Informa Ltd Registered in England and Wales Registered Number: 1072954 Registered office: Mortimer House, 37-41 Mortimer Street, London W1T 3JH, UK.
}

Untuk lebih mengarahkan penelitian, masalah stigma Penasun ini diidentifikasi sebagai berikut:

a. Bagaimana KPA kabupaten Sumedang melaksanakan kegiatan promosi kesehatan penanggulangan HIVAIDS?

b. Bagaimana Penasun memaknai stigma yang dialaminya?

c. Bagaimana Penasun memaknai kegiatan promosi kesehatan dalam menghapuskan stigma?

\section{METODE}

Metode studi kasus cocok untuk meneliti kelompok Penasun, karena peneliti tidak memiliki otoritas dan kemampuan untuk mengontrol subjek riset. Selain itu, secara umum pokok pertanyaan dalam penelitian ini berkenaan dengan Bagaimana ${ }^{5}$, sehingga memungkinkan peneliti untuk karakteristik holistik dan bermakna pada peristiwa-peristiwa kehidupan nyata seperti stigmatisasi yang dialami para kelompok Penasun ini. Data penelitian dikumpulkan melalui: wawancara mendalam, observasi dan studi pustaka.

Populasi dalam penelitian ini adalah beberapa penasun yang telah dijangkau dan didampingi LSM dan KPA Kabupaten Sumedang serta anggota masyarakat lainnya yang dipilih, melalui beberapa kriteria yang telah ditentukan secara purposive.

AIDS atau Acquired Immune Deficiency Syndrom adalah sekumpulan gejala penyakit, yang timbul karena turunnya kekebalan tubuh. AIDS disebabkan oleh adanya virus HIV (Human Immunodeficiency Virus) di dalam tubuh yang menyerang dan merusak sistem kekebalan tubuh. Virus HIV ini hidup dalam empat cairan tubuh manusia: cairan darah, cairan sperma, cairan vagina, Air Susu Ibu.

Beberapa hal di bawah ini adalah alasan, mengapa pemerintah setiap negara perlu memberi perhatian khusus terhadap penyakit AIDS:

a. Belum ada obatnya dan belum ada vaksin yang bisa mencegah.

b. Pengidap virus menjadi pembawa dan dapat menularkan penyakit seumur hidupnya, walaupun tidak merasa sakit dan tampak sehat.

c. Biaya pengobatan mahal.

d. Menurunkan mutu sumber daya manusia dan produktifitas kerja, sehingga dapat mengganggu perekonomian negara.

e. Penyakit ini telah menyebar dengan cepat ke seluruh dunia, sebagian besar ditularkan melalui hubungan seks.

\section{Promosi Kesehatan}

Terkait pentingnya penyebaran informasi HIVAIDS pada masyarakat secara tepat, maka pemerintah

${ }^{5}$ Lihat Yin, Studi Kasus, Desain \& Metode, 2002:1, Raja Grafindo Persada, Jakarta. 
menggulirkan program Promosi Kesehatan (yang dalam perspektif komunikasi, terminologi Promosi Kesehatan ini dapat diartikan sebagai sosialisasi program-program kesehatan. Promosi kesehatan ini dicanangkan dengan harapan masyarakat dapat mengetahui tanda-tanda seseorang tertular HIV, dimana sebenarnya tidak ada hal khusus yang bisa menandai apakah seseorang telah tertular HIV, karena keberadaan virus HIV sendiri membutuhkan waktu yang cukup panjang (5 sampai 10 tahun hingga mencapai masa yang disebut fullblown AIDS). Secara umum, seperti dikutip dari Saleha et al dalam jurnal Sosiohumaniora Vol 18 no 1 Maret 2016 6 promosi kesehatan merupakan upaya pemerintah dalam meningkatkan kualitas kesehatan masyarakat sehinga diperlukan strategi komunikasi agar program dapat tercapai dengan efektif dan efisien. Secara legal, promosi kesehatan diatur dalam SK Menteri Kesehatan no 1193/Menkes/SK/X/2004 tentang Kebijakan Nasional Promosi Kesehatan. Bahkan untuk promosi kesehatan di daerah secara spesifik pemerintah mengaturnya dalam SK no 1114/Menkes/ SK/VII/2005 tentang Pedoman Pelaksanaan Promosi Kesehatan di Daerah.

\section{Pengguna Narkoba Suntik (Penasun)}

Penasun atau pengguna Narkoba Suntik termasuk pada populasi kunci penyebaran HIV-AIDS, oleh karenanya, penanganan khusus pada kaum Penasun agar bisa mengurangi dampak buruk penggunaan obat terlarang dengan cara suntik ini menjadi sebuah keniscayaan.

Istilah pengurangan dampak buruk berasal dari terjemahan Harm Reduction yang berarti pengurangan/ penurunan kerugian/kerusakan. Pengurangan dampak buruk obat terlarang merupakan bentuk konsep program yang digunakan untuk mencegah atau mengurangi konsekuensi negatif yang berkaitan dengan perilaku penggunaanobat terlarang , khususnya dengan cara suntik. Program ini bertujuan mencegah penularan HIV pada kelompok penasun dan pasangannya. Tujuan ini lebih bersifat jangka pendek dan pragmatis dari pada tujuan jangka panjang berupa penghentian penggunaan obat terlarang. Penasun menjadi sasaran utama (primer) sedangkan pengguna obat terlarang yang lain dan pasangan seks Penasun serta keluarganya menjadi sasaran sekunder, dan masyarakat luas menjadi sasaran tersier.

\section{Stigma}

Secara konseptual, dalam perspektif Ilmu komunikasi, Stigma biasanya merujuk pada hasil penelitian Erving Goffman dalambukunya Notes on the Management of Spoiled Identity (1963), yang menyatakan bahwa,

"the concept of stigma refers to negative stereotypes assigned to a people when their attributes are considered both different from or inferior to societal norms. Stigma was about the social interactions

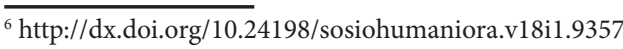

between 'stigmatized' and 'normal' persons in society. The process of stigma is deeply discrediting"

Stigma adalah situasi dimana seseorang mengalami diskualifikasi dari penerimaan sosial secara penuh, " the situation of the individual who is disqualified from full social acceptance". 7

Goffman menyatakan bahwa stigma adalah jarak yang terjadi antara identitas sosial virtual dengan identitas sosial aktual. Orang yang mengalaminya disebut orang yang terstigmatisasi. Stigma dan stigmatisasi adalah tanda yang terlihat untuk menunjukkan insider dan outsider serta memunculkan ketidakberdayaan \& ketidakadilan sosial. Stigma mampu menghancurkan dan mengganggu identitas serta menghalangi partisipasi masyarakat. (Bruce.G.Link dalam Mubarok, 2010: 18).

Kata "stigma" juga dipergunakan dalam istilah "stigma sosial", yaitu tanda bahwa seseorang dianggap ternoda dan karenanya mempunyai watak yang tercela, misalnya seorang bekas narapidana yang dianggap tidak layak dipercayai dan dihormati. Stigma sosial bisa beragam bentuknya tergantung pada konteks sosio politik dan geopolitik suatu negara, tetapi biasanya stigma sosial akan ditempelkan pada orang atau sekelompok orang yang oleh masyarakat dianggap keluar dari norma sosial yang ada, misalnya sakit mental, cacat fisik, penyakit tertentu seperti Leprosy, HIV-AIDS, kelainan seksual, pecandu narkoba, residivist, agama, warna kulit, etnik, ideologi, pendidikan atau kriminalitas.

Jadi intinya, menurut Goffman, stigma sesungguhnya adalah jenis khusus dari hubungan antara atribut dan stereotipe, "really a special kind of relationship between attribute and stereotype” (1963 : 14). Goffman juga memaparkan bahwa dampak dari adanya Stigma di masyarakat dapat mengganggu sumber daya manusia, kesempatan hidup sehat, bahkan penganiayaan berupa marginalisasi dan diskriminasi.

Lebih jauh Goffman menyatakan bahwa stigma mencerminkan nilai-nilai sosial yang ada di masyarakat, dimana apa yang tidak bisa diterima pada masa lalu, menjadi sesuatu yang bisa diterima pada hari ini, atau sebaliknya apa yang di masa lalu bisa diterima, malah pada hari ini menjadi sesuatu yang janggal dan tidak diterima, bahkan juga tidak hari ini tapi juga di masa depan, bisa saja sesuatu saat ini bisa diterima atau sebaliknya, tetapi menjadi tidak diterima atau sebaliknya untuk masa yang datang.

"Stigma reflects cultural shifts in norms What was acceptable in the past may be unacceptable today. What was unacceptable in the past may be acceptable today. What is unacceptable today may be acceptable in the future. What is acceptable today may be unacceptable in the future." (Goffman: 1963).

Erving Goffman, Stigma: Notes on The Management of Spoiled Identity, 1963, Penguin, London, page: 10.” 


\section{Teori Labeling}

Stigma sebetulnya terkait erat dengan Teori Labeling, bahkan kontributor terpenting dalam Teori Labeling adalah Erving Goffman, dalam karyanya The Presentation of Self in Everyday Life, yang lebih rinci menguraikan khusus tentang stigma dalam bukunya Stigma: Notes on the Management of Spoiled Identity terbit tahun 1963.

"Unlike other authors who examined the process of adopting a deviant identity, Goffman explored the ways people managed that identity and controlled information about it. Several studies have indicated that most people associate being labeled mentally ill as being just as, or even more, stigmatizing than being seen as a drug addict, ex-convict, or prostitute " (Brand \& Claiborn 1976). ${ }^{8}$

Merujuk pada kutipan di atas, bahwa teori Labeling juga banyak diterapkan untuk kajian-kajian seperti sakit mental (mentally ill), kecanduan obat, prostitusi, maka Penasun atau pengguna narkoba suntik yang menjadi subjek penelitian ini, nampaknya relevan jika dianalisis dengan menggunakan Teori Labeling.

"Labeling theory is the theory of how the self-identity and behavior of individuals may be determined or influenced by the terms used to describe or classify them. It is associated with the concepts of self-fulfilling prophecy and stereotyping. Labeling theory holds that deviance is not inherent to an act, but instead focuses on the tendency of majorities to negatively label minorities or those seen as deviant from standard cultural norms. The theory was prominent during the 1960s and 1970s, and some modified versions of the theory have developed and are still currently popular. Unwanted descriptors or categorizations - including terms related to deviance, disability or diagnosis of a mental disorder - may be rejected on the basis that they are merely "labels", often with attempts to adopt a more constructive language in its place. A stigma is defined as a powerfully negative label that changes a person's self-concept and social identity." 9

\section{HASIL DAN PEMBAHASAN}

\section{Situasi Endemi HIV-AIDS di Sumedang}

Kegiatan promosi kesehatan pencegahan dan penanggulangan HIV-AIDS di Kabupaten Sumedang semakinterstruktursetelahmemilikipayunghukumberupa Peraturan Daerah no 5 tahun 2013 tentang Pencegahan dan Penanggulangan Human Immunodeficiency Virus dan Acquired Immuno Deficiency Syndrome.

Kabupaten Sumedang memiliki jumlah populasi berdasarkan registrasi penduduk tahun 2012 sebanyak 1.393.602 jiwa yang terdiri dari : 690.797 perempuan, 692.805 laki-laki. Terkait Situasi Epidemi HIV/AIDS

\footnotetext{
${ }^{8}$ Wikipedia, diunduh Agustus 2014

${ }^{9}$ Wikipedia, diunduh Agustus 2014
}

Kabupaten Sumedang, orang yang memiliki status positif HIV/AIDS dapat ditemukan hampir di semua kecamatan (22 kecamatan), kecuali di Kecamatan Cisitu. Dan kasus HIV/AIDS di kabupaten Sumedang selama 10 tahun terakhir ini cenderung tidak berubah, kecuali sempat mengalami peningkatan pada tahun 2013.

Berdasarkan jenis kelamin, kasus HIV-AIDS di Kabupaten Sumedang kendati laki-laki lebih banyak daripada perempuan, tetapi selisihnya tidak terlalu jauh, yaitu laki-laki (53\%), perempuan (44\%) sisanya (3\%) tidaksecara jelas menyatakan dirinya laki-laki atau peempuan. Adapun usia pertama kali terinveksi, kelompok usia 21-30 tahun menempati posisi paling tinggi, yaitu sejumlah 169 orang. Kemudian pada urutan kedua kelompok usia 31-40 tahun sebanyak 54 orang dan posisi ketiga kelompok usia 41-50 tahun 10 orang. Nampak dari data ini bahwa usia pertama kali etrinveksi berada pada rentang usia produktif antara 21-50 tahun.

Data Dinas Kesehatan Sumedang mencatat, perilaku masyarakat yang menjadi pemicu Penularan HIV-AIDS ini, yaitu yang paling tinggi resikonya adalah akibat bergonta ganti pasangan (45\%) dan penggunaan NAPZA suntik/Penasun (29\%). Pasangan laki-laki yang suka berhubungan seksual dengan Wanita Pekerja Seksual (WPS) juga memiliki resiko cukup tinggi yaitu $8 \%$, ibu hamil yang positif HIV-AIDS juga dapat menularkan ke anaknya (5\%), pasangan Penasun (3\%) dan pasangan WPS (3\%).

Jika dibandingkan dengan jumlah penduduk Kabupaten Sumedang yaitu 1.393 .602 jiwa, maka pemicu epidemi HIV 110.382 (20\%) orang diantaranya adalah laki-laki dewasa yang senang membeli Seks dan 560.245 perempuan yang menikah dengan resiko tinggi.

\section{Strategi Pencegahan \& Penanggulangan HIV-AIDS}

Dari hasil observasi dan wawancara mendalam dengan para informan, peneliti mencermati kegiatan Promosi Kesehatan yang dilakukan KPA Sumedang untuk mencegah dan menanggulangi penularan HIV-AIDS terutama di kalangan Penasun di Jatinangor, nampaknya sudah berjalan sesuai dengan panduan operasional yang dibuat oleh Departemen Kesehatan. Kegiatan promosi kesehatan dibagi menjadi empat bagian yaitu : 1) advokasi, 2) Bina Suasana melalui media massa \& media sosial, 3) Pemberdayaan masyarakat serta 4) Kemitraan. Selain itu, setiap kegiatan dilakukan melalui beberapa tahapan, mulai dari a) perencanaan, b) pelaksanaan sampai c) evaluasi kegiatan.

Secara konseptual, apa yang dihadapi oleh KPA Sumedang ini nampaknya sejalan dengan apa yang dikemukakan oleh Melanie Rembrandt dalam artikelnya "Nonprofit Organizations Are At Work On Issues Of Critical Social Importance.", bahwa untuk keberhasilan kerja organisasi non profit seperti KPA, mereka menghadapi tantangan untuk mampu mengedukasi, 
memotivasi memobilisasi publik yang biasanya justru terlalu sering stres berkepanjangan dan bahkan apatis. "To succeed, they face the challenge of trying to educate, motivate and mobilize a public that is too often stressed out, overextended, even apathetic." 10

Seperti dikemukakan Budhi, pendamping seorang Penasun yang sudah positif HIV-AIDS di Jatinangor, " kedah sabar bu mendampingi ODHA mah, kadang cageur tapi seringna mah ngedrop mentalna teh, malihan aya nu tos pasrah, cuek bari apatis, da istilahna teh naon deui kari ngantosan maot ieuh (harus sabar bu mendampingi ODHA ini, kadang sembuh tapi lebih sering turun mentalnya, malahan ada yang sudah pasrah, tidak peduli sambil apatis, karena istilah mereka mau apa lagi hanya tinggal menunggu mati ini)"

KPA Sumedang, melalui kegiatan promosi kesehatan, mencoba mengkomunikasikan apapun tentang bahaya HIV-AIDS termasuk kepada kelompok Penasun dengan menggunakan berbagai media. Ini terlihat dari berbagai pesan yang dirancang KPA, ada yang menggunakan bahasa Sunda seperti spanduk, poster, T-Shirt dan brosur, mengingat masyarakat Sumedang mayoritas penduduknya adalah etnis Sunda dan berbahasa Sunda.

Dari dokumentasi KPA Sumedang, nampak strategi promosi melalui Media massa dilakukan dengan menggunakan bahasa Sunda, ikon tokoh wayang si Cepot yang dikemas dalam berbagai bentuk seperti standing banner, T-shirt, poster, leaflet, brosur, dan lainlain.

Adapun strategi Targeted-Multi Media Promotion (TMCC), pada prinsipnya adalah kegiatan yang dilakukan melalui media sosial yang menurut Tita dilakukan dalam beberapa kegiatan yaitu:

a. Penyebarluasan pesan HIV dan AIDS yang telah disusun di pusat dan provinsi, khusus melalui chatting, facebook dan twitter dan SMS gateway.

b. Penyusunan dan penyebarluasan pesan HIV dan AIDS sesuai kebutuhan kab Sumedang melalui TMMC.

c. Advokasi kepada pemilik/pengelola channel chatting dan provider telekomunikasi

Budhi Nugraha, salah satu pendamping senior di KPA Sumedang menjelaskan bahwa KPA Sumedang memiliki akun facebook dengan nama KPA Kab. Sumedang begitu juga twiter. Tetapi diantara dua jenis media sosial ini, yang paling aktif adalah media facebook. "Selain FB dan twiter, kami juga memiliki layanan SMS, tetapi ini tidak seaktif FB" ujar Budhi. ${ }^{11}$

Selain melalui media Sosial berupa facebook dan twiter serta SMS, Budhi menyatakan KPA Sumedang juga menggunakan radio lokal Sumedang yaitu radio Yusyan dan radio RKS dalam bentuk talkshow langsung

\footnotetext{
${ }^{10}$ Rembrandt Communications, LLC, 2010, diunduh Maret 2010.

${ }^{11}$ Wawancara tanggal 15 Oktober di sekretariat KPA Sumedang.
}

dengan nara sumber orang yang sudah positif HIVAIDS atau ODHA.

"Kami sampai menghadirkan ODHA untuk berbicara langsung di radio kepada masyarakat Sumedang tentang bahaya HIV-AIDS"

ujar Budhi sambil menambahkan bahwa promosi melalui TV pernah dilakukan berupa iklan layanan masyarakat melalui TV lokal SMTV (Sumedang TV). Secara konseptual, apa yang dilakukan oleh KPA Sumedang sejalan dengan pernyataan para ahli komunikasi strategis bahwa, "Good communication cuts through the clutter, it doesn't add to it. It does this by getting the right message, in the right medium, delivered by the right messengers, to the right audience ${ }^{12}$.

Media komunikasi yang nampak dalam gambar di atas, sejalan dengan prinsip penyampaian pesanpesan secara strategis yakni: "Clear, Simple, Concise Messages" juga "Specify What People Should Do" serta prinsip Match Strategy And Tactics To Your Target Audience." seperti dikemukakan Dennis \& Wilcox dalam bukunya Strategi \& Taktik PR. ${ }^{13}$

Selain itu, KPA menerapkan strategi dan taktik komunikasi, dimana semua kegiatan promosi kesehatan, dilakukan dalam beberapa tahap yaitu, diawali dengan membuat 1) pemetaan dan kajian kebijakan, kemudian 2) sosialisasi pemetaan dan kebijakan, 3) pelaksanaan advokasi ke Bupati/Walikota, DPRD dan Bapeda, 4) Mendokumentasikan hasil-hasil utama kegiatan advokasi. Jika dirujuk pada konsep komunikasi efektif, hal ini sesuai dengan prinsip "Clear Goals, Measurable Progress" serta prinsip "Budget For Success". 14

Definisi Promosi kesehatan menuurt undangundang kesehatan adalah upaya untuk meningkatkan kemampuan masyarakat melalui pembelajaran dari, oleh, untuk dan bersama masyarakat, agar mereka dapat menolong dirinya sendiri, serta mengembangkan kegiatan yang bersumber daya masyarakat sesuai sosial budaya setempat dan didukung oleh kebijakan publik yang berwawasan kesehatan.

Mengacu pada definisi di atas, maka Promosi kesehatan dalam konteks penelitian ini adalah "upaya untuk meningkatkan kemampuan masyarakat melalui pembelajaran dari, oleh, untuk dan bersama masyarakat, agar para Penasun dapat menolong dirinya sendiri, serta mengembangkan kegiatan yang bersumber daya masyarakat sesuai sosial budaya setempat dan didukung oleh kebijakan publik yang berwawasan kesehatan.

Populasi pengguna narkoba suntik di Kabupaten Sumedang, berdasarkan data yang ada di KPA Sumedang, tersebar pada berbagai kelompok masyarakat di 26 komunitas.

\footnotetext{
${ }^{12}$ Ibid

${ }^{13}$ Strategi dan Taktik PR, Dennis Wilcox et al, 2000

14 ibid
} 
Jatinangor, seperti dinyatakan staf sekretariat KPA Tita Anarita ${ }^{15}$, merupakan wilayah yang paling banyak Penasunnya. Hal ini mungkin disebabkan oleh karakteristik wilayah Jatinangor sebagai wilayah pendidikan dan industri, dimana masyarakatnya cukup heterogen dan lebih dominan masyarakat pendatang seperti mahasiswa dan buruh.

Menurut Tita, populasi Penasun di wilayah Jatinangor tidak hanya mahasiswa, tetapi juga menyebar ke hampir semua kalangan seperti pelajar, ibu rumah tangga, pedagang, tukang ojeg, dan masyarakat pekerja. "Bahkan Penasun sudah bukan populasi kunci lagi Teh, tapi sudah bergeser jadi populasi" jelas Tita.

Terkait cukup banyaknya populasi Penasun di Jatinangor, maka KPA Sumedang memiliki berbagai program khusus untuk kelompok Penasun diselaraskan dengan program KPA pusat. Salah satu program yang baru saja dilaksanakan adalah bakti sosial dengan komunitas Penasun, berupa kegiatan "membersihkan limbah jarum suntik di Puskesmas Jatinangor".

Kegiatan ini tujuan utamanya adalah untuk menyosialisasikan tentang bahaya penyebaran HIVAIDS melalui penggunaan jarum suntik yang tidak steril. Kegiatan ini bekerjasama dengan Pusat Informasi Kesehatan Masyarakat (PIKM) yang merupakan kumpulan komunitas Penasun.

"iya PIKM itu semacam tempat ngumpulnya atau tempat saling curhatnya kaum Penasun. Ini jadi memudahkan kami untuk memantau dan mengontrol aktivitas narkoba mereka" jelas Budi ${ }^{16}$.

Lebih jauh dijelaskan Tita, selain upaya memberikan pengetahuan tentang bahaya jarum suntik tidak steril tersebut, pemerintah juga, melalui KPA melakukan substitusi jarum suntik steril dan langsung menarik jarum suntik bekas pakai.

Lebih rinci Tita menjelaskan bahwa dalam upaya mencegah penularan HIV -AIDS, pemerintah telah mengirim paket ke KPA-KPA daerah di seluruh Indonesia.

"Paket tersebut berisi, jarum suntik steril, kondom, kapas pembersih beralkohol, termasuk alat pemungut jarum suntik bekas pakai serta storage / wadahnya." Ungkap Tita.

Dijelaskan Tita, paket-paket tersebut didistribusikan oleh KPA ke Puskesmas-Puskesmas melalui Dinas Kesehatan.

"Pada prakteknya untuk mendistribusikan paket ini, kami bekerjasama dengan mitra dan juga melibatkan masyarakat, karena sebelumnya kami sudah membentuk WPA (Warga Peduli AIDS)" ungkap Tita, sambil menambahkan bahwa dari sekitar 100 jarum

\footnotetext{
${ }^{15}$ Pengelola program dan monev KPA Sumedang, Wawancara tanggal 15 September 2014 di sekretariat KPA Sumedang

${ }^{16}$ Ketua Dewan Kesehatan Rakyat Kab. Sumedang, wawancara tanggal 15 september 2014 di sekretariat DKR Sumedang.
}

suntik yang didistribusikan ke Penasun, yang kembali paling hanya $10 \%$. Itu makanya kami mengadakan bakti sosial membersihkan limbah jarum suntik bekas pakai, sebagai upaya mengumpulkan dan melokalisir sebanyak mungkin jarum suntik bekas pakai, agar tidak disalahgunakan lagi”" tambah Tita. ${ }^{17}$

\section{Makna Stigma Penasun}

Hasil perbincangan dengan para informan, diperoleh data bahwa mereka merasa sangat kesal dengan adanya stigma dari masyarakat, karena menurut mereka, sesungguhnya mereka juga tidak mau terjerat narkoba, tetapi sangat sulit untuk bisa melepaskan diri. Bahkan dengan adanya stigma, mereka merasa makin putus asa dan makin terbelit dalam ketergantungan narkoba.

"Padahal mah bu, kita juga da ga mau atuh hidup kayak gini teh, tapi da kumaha deui, geus terlanjur dicap runtah atuh kita mah bu." ungkap $\mathrm{R}$, salah seorang Penasun yang hanya tamat SMP dan bekerja sebagai tukang Ojeg. ${ }^{18}$

Para penasun merasa kesal dan nyaris putus asa, karena mereka tidak merasa merugikan masyarakat dengan perilakunya tersebut, bahkan mereka justru minta dibantu oleh masyarakat agar bisa terlepas dari jeratan narkoba ini.

"Sok kesel bu abi mah, mun anak tatangga, dicarek ulin jeung abi ku kolotna, cenah sieun kababawa, padahal da abi mah tara ngangajak teu bener siga abi kieu ka batur mah. Ngan hayang ulin bareng wungkul, meni disieuhkeun siga ka hayam." ungkap informan A, yang bekerja serabutan sebagai buruh kasar. ${ }^{19}$

Hal ini juga dialami oleh Keong (nama samaran), warga Cibeusi lulusan SMA yang belum menikah ini menyatakan, "saya suka disisihkan oleh masyarakat, saya suka dibilang ga bener, tukang narkoba, saya kalo nyamper temen suka digaadakan, karena saya dibilang orang ga bener.' 20

Begitu juga yang dialami Penasun HDR, warga Cibeusi kelahiran Sumedang yang sudah menikah dan tamat SMA ini mengungkapkan tentang stigma yang dialaminya,

"Saya pingin masyarakat lebih percaya bahwa saya waloupun pemake tapi saya ga bakalan ngajak anakanaknyah. Kadang saya suka kesal karena saya jadi jauh dari masyarakat"21

Selain dilarang bergaul dengan anak-anak sebayanya, para penasun ini juga merasa diperlakukan

\footnotetext{
${ }^{17}$ Wawancara mendalam dengan informan Tita dari KPA Sumedang, oktober 2014.

${ }^{18}$ Wawancara mendalam dengan informan R, oktober 2014.

${ }^{19}$ Wawancara mendalam dengan informan A, oktober 2014.

${ }^{20}$ Wawancara mendalam dengan informan Keong (nama samaran), oktober 2014.

${ }^{21}$ Wawancara mendalam dengan informan HDR, oktober 2014
} 
buruk oleh masyarakat, seperti yang disampaikan oleh informan kelahiran Medan dan keturunan Tionghoa yang sudah lama menjadi warga Jatinangor, "saya merasa terisolasi, apalagi orang merasa risih jika dekatdekat dengan saya" ${ }^{22}$ Apur, Penasun kelahiran Blora dengan etnik Jawa, juga menyatakan " merasa diri seperti dikucilkan, tidak pernah dianggap oleh orang lain dan tidak dihargai"

Dari beberapa ungkapan jujur para penasun ini, peneliti menyimpulkan bahwa para penasun menyadari adanya stigma terhadap mereka, dan mereka merasa tidak senang dengan stigma masyarakat ini. Di sisi lain, kaum Penasun juga tidak berdaya melepaskan diri dari jeratan narkoba dan menerima stigma sebagai resiko yang harus dihadapi.

Seperti diungkapkan oleh Penasun Ariel, Warga Kampung Bojong eureun yang sudah menikah dan bekerja sebagai karyawan di sebuah Toko di Jatinangor,

"saya merasa kesal, karena sudah jelas menurut masyarakat hal yang kami lakukan ini negatif, namun kami tidak bisa berbuat banyak karna hanya kamilah yang tahu. Yang jelas kami melakukan hal ini karna tuntutan dari apa yang kami alami." ${ }^{23}$

Dari hasil wawancara dengan 12 orang Penasun di kawasan jatinangor ini, dapat dicermati pada model di bawah ini, bagaimana mereka memaknai stigma yang dilaminya sebagai Penasun.

Kendati semua informan menyatakan ingin diterima oleh masyarakat, tetapi ketika ditanya bagai-mana mereka menghadapi stigma masyarakat tersebut, beberapa informan menyatakan pasrah dan menerima dengan cara berdiam diri di rumah, satu orang memilih tetap bergaul di masyarakat tetapi dengan sikap cuek, dan hanya satu orang yang menyatakan berusaha membuktikan pada masyarakat dengan cara tetap bersosialisasi dan membantu kegiatan warga.

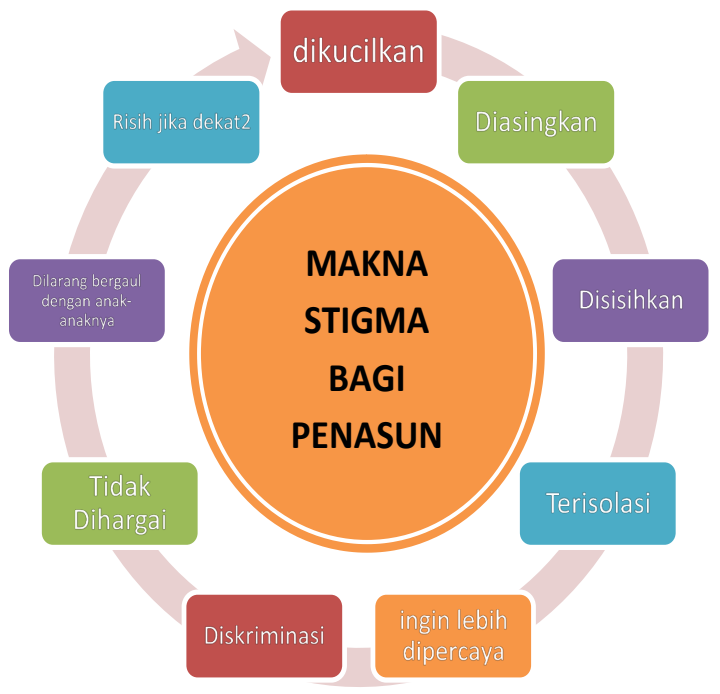

Gambar 1. Makna Stigma Bagi Penasun

\footnotetext{
${ }^{22}$ Wawancara mendalam dengan informan S, oktober 2014.

${ }^{23}$ Wawancara mendalam dengan informan Ariel, oktober 2014.
}

Hasil wawancara mendalam dengan para Penasun dari kalangan pelajar yang menjadi informan dalam penelitian ini memperlihatkan bahwa, stigma yang dialami Penasun, cenderung membuat mereka menjadi semakin mengisolasi diri dari masyarakat luas. Mereka memilih lebih banyak berdiam diri di rumah, bersikap cuek atau masa bodoh, atau kalaupun berinteraksi, cenderung hanya dengan kelompok atau komunitasnya sendiri. Walaupun ada juga beberapa Penasun yang berupaya membuka komunikasi dengan masyarakat yang menstigmanya dengan cara tetap bersosialisasi, membantu dan aktif dalam setiap kegiatan masyarakat dan bahkan masuk organisasi atau LSM. Muara dari upaya-upaya Penasun sebetulnya ingin dipercaya dan diterima oleh masyarakat.

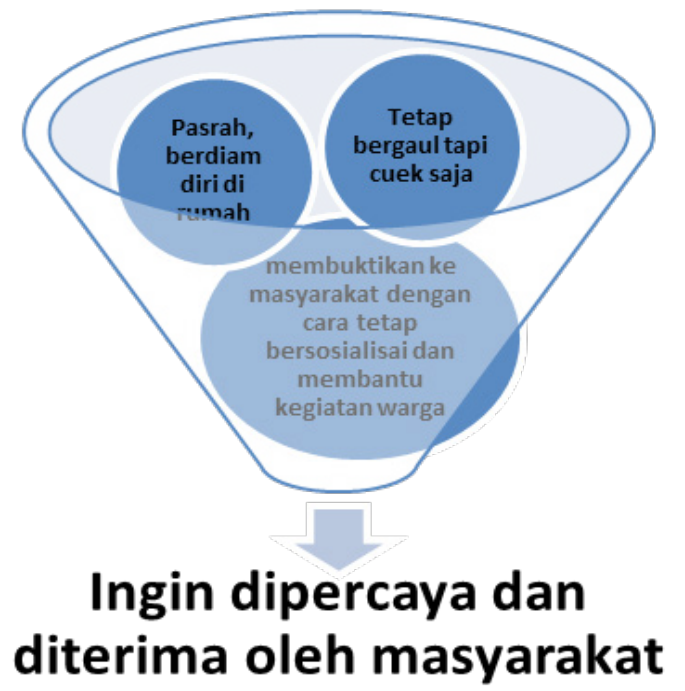

Gambar 2. Upaya Penasun Pelajar menghadapi Stigma

Berbeda dengan upaya Penasun pelajar yang lebih banyak memilih berdiam diri di rumah, kelompok Penasun mahasiswa memiliki upaya yang cenderung lebih banyak alternatifnya, seperti nampak pada bagan dibawah ini,



Gambar 3. Upaya Penasun Mahasiswa dalam menghadapi Stigma 
Menurut penuturan para informan, sebelum terjerat pada perilaku buruk mengkonsumsi narkoba bahkan kemudian menjadi pecandu, kehidupan mereka normal-normal saja, dalam arti mereka memiliki konsep diri yang positif dan identitas sosial yang juga positif, misalnya sebagai pelajar atau sebagai remaja baik-baik di kampungnya. Mereka juga biasa bersosialisasi dengan teman sebaya baik di lingkungan sekolah maupun di lingkungan tempat tinggalnya. Namun keadaan menjadi berubah ketika mereka mulai mencoba-coba mengkonsumsi narkoba, rata-rata terjadi karena ajakan teman atau ikut-ikutan karena takut dianggap tidak "guyub" atau tidak setia kawan oleh kelompoknya.

Dampak buruk narkotika dan obat terlarang yang mereka konsumsi menjadikan perilaku mereka yang tadinya manis dan baik, cenderung menjadi tidak terkontrol, mudah tersulut emosinya, dan menghindari aktivitas positif bersama serta lebih suka menarik diri dari pergaulan.

Perubahan perilaku ini kemudian memicu perubahan sikap dari masyarakat, bahkan jika kemudian masyarakat tahu bahwa mereka adalah pengguna narkoba, maka serta merta masyarakat akan menghukum mereka secara sosial, karena dianggap telah melakukan penyimpangan dari norma-norma sosial yang ada.

Kelompok Penasun kelas mahasiswa juga mengungkapkan lebih anyak pemikirannya tentang stigma, diantaranya adalah kendala yang mereka hadapi saat melakukan berbagai upaya menghadapi stigma masyarakat, seperti nampak dalam bagan berikut,

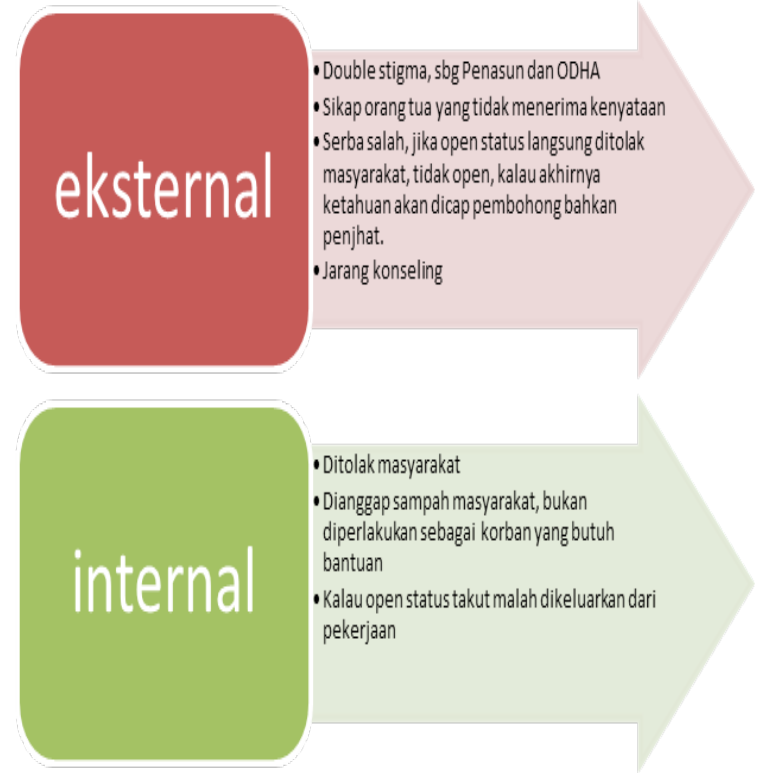

\section{Gambar 4. Kendala yang dihadapi Penasun}

Penyimpangan perilaku dari nilai-nilai moral dan norma sosial yang ada di masyarakat akan melahirkan labelling atau pelabelan pada mereka, seperti dikemukakan Mead, "If deviance is a failure to conform to the rules observed by most of the group, the reaction of the group is to label the person as having offended against their social or moral norms of behavior. "
Bahkan masyarakat memiliki kekuatan untuk menunjuk pelaku pelanggaran aturan mereka sebagai orang sesat dan masyarakat bisa memberikan ancaman pada mereka, misalnya dilarang bergaul dengan anakanak dari keluarga baik-baik, bahkan ada yang sampai diusir dari lingkungan tempat tinggalnya.

Hal ini diungkapkan oleh salah seorang informan yang mengaku bahwa setelah masyarakat tahu dirinya seorang Penasun, orang tuanya didatangi pengurus RT setempat dan diminta untuk menjauhkan anaknya yang pecandu dari lingkungan mereka.

"wah Bu, abdi mah dugi ka diusir atuh ku pa RT, pun biang dugi ka teu damang wales gara-gara eta teh, tapi teu digugu ah bu, da bade ngalih kamana atuh, teu gaduh deui tempat abdi mah. Tungtungna ceuk $R T$ teh, nya sok lah teu pindah oge teu nanaon, tapi maneh mun rek ngobat tong di lingkungan ieu, jig we di luar, jauh ti dieu nya. Tah Bu dugi ka kitu, nya beuki ancur we atuh abdi teh" ( wah Bu, saya sampai diusir oleh pa RT, ibu saya sampai sakit keras gara-gara hal ini, tapi tidak saya gubris ah bu, mau pindah kemana, karena saya tidak punya lagi tempat. Akhirnya kata RT, ya sudah tidak pindah juga tidak apa-apa, tapi kamu kalau mau pakai obat jangan di lingkungan ini, silakan saja di luar, jauh dari sini ya. Nah Bu sampai seperti itu, ya semakin hancur saja saya ini) ${ }^{24}$

Hal ini sejalan dengan apa yang disampaikan Mead (1937),

"This is the power of the group: to designate breaches of their rules as deviant and to treat the person differently depending on the seriousness of the breach. The more differential the treatment, the more the individual's self-image is affected."

Bahwa kelompok masyarakat memiliki kekuasaan untuk menghukum pelanggaran atas aturan yang berlaku di lingkungannya. Seperti halnya pa RT yang menghukum Penasun HDR ini untuk pindah atau keluar dari lingkungan komplek perumahan tersebut karena dianggap HDR telah melanggar norma moral dan norma sosial yang berlaku.

Perilaku Penasun yang dianggap sebagai penyimpangan dari norma moral dan norma sosial di masyarakat telah memberi label negatif pada diri Penasun, sehingga lambat laun, citra diri mereka menjadi terpengaruh secara negatif, artinya baik konsep diri maupun identitas sosialnya menjadi negatif, inilah yang disebut Stigma. Seperti dikemukakan Mead ( 1937), a stigma is defined as a powerfully negative label that changes a person's self-concept and social identity.

Secara konseptual, hal ini juga dijelaskan dalam Teori Labeling yang menyatakan bagaimana identitas diri dan perilaku seseorang mungkin ditentukan atau dipengaruhi oleh istilah yang digunakan untuk menggambarkan atau

${ }^{24}$ Wawancara dengan informan HDR, tanggal 15 Oktober 2014 
mengklasifikasikan mereka. "Labeling theory is the theory of how the self-identity and behavior of individuals may be determined or influenced by the terms used to describe or classify them".

Lebih jauh George Herbert Mead (1937) mengemukakan, bahwa diri dikonstruksi dan direkonstruksi secara sosial melalui interaksi seseorang dengan masyarakat, dan Teori Labeling menyatakan bahwa seseorang mendapatkan label dari bagaimana orang lain memandang kecenderungan mereka berperilaku.

"that the self is socially constructed and reconstructed through the interactions which each person has with the community. The labeling theory suggests that people obtain labels from how others view their tendencies or behaviors."

Dalam konteks Penasun, merujuk pada Mead, bahwa masyarakat menempelkan label tersebut dari bagaimana orang lain memandang akan kecenderungan kelompok Penasun berperilaku (how others view their tendencies or behaviors). Kendati para informan membantah hal ini dan menyatakan bahwa perilaku menggunakan narkoba suntik hanya sebatas untuk dirinya saja dan tidak akan mengajak orang lain, namun masyarakat tetap menempelkan label bahwa kelompok Penansun ini cenderung akan berperilaku negatif dalam segala hal, misalnya mempengaruhi teman-temannya untuk ikut mengkonsumsi narkoba, berbuat kriminal seperti mencuri, memeras, merampas barang milik orang lain, memancing keributan dan menimbulkan keonaran. Label Penasun diikuti dengan label kriminal lainnya, seperti pencuri, pengacau, pemeras dan lain-lain. Kendati bisa saja perbuatan negatif tersebut tidak mereka lakukan, tapi label sudah melekat dan bahkan ada yang kemudian menjadi pendorong untuk disengaja dilakukan.

“ Da keuheul atuh bu, mun aya nu kaleungitan barang teh langsung we dituduhkeun ka abi, nya geus we sakalian dihajakeun (habis kesal bu, kalau ada yang kehilangan barang langsung menuduh saya, jadi ya sudah sengaja saya lakukan saja)’”25

Hal ini sejalan dengan apa yang diungkapkan Mead(1937) bahwa sementara masyarakat menggunakan label stigma untuk membenarkan hukuman tersebut, aktor menyimpang menggunakannya untk membenarkan tindakannya, "while society uses the stigmatic label to justify its condemnation, the deviant actor uses it to justify his actions."

Setiap individu menyadari bahwa mereka dinilai oleh orang lain karena mereka telah berusaha memainkan berbagai peran dan fungsi yang berbeda dalam interaksi sosial dan telah dapat mengukur reaksi atas perilaku tersebut.

\footnotetext{
${ }^{25}$ Wawancara dengan Penasun Apur, oktober 2014.
}

"Each individual is aware of how they are judged by others because he or she has attempted many different roles and functions in social interactions and has been able to gauge the reactions of those present."

Demikian juga para Penasun, mereka cukup sadar bahwa penilaian negatif yang mereka terima saat ini, karena mereka telah memainkan peran dan fungsi yang berbeda dalam interaksi mereka dengan masyarakat. Ketika yang lain patuh memainkan peran dan fungsi sosial sebagai pemuda baik, taat, sopan, dan bermoral, sementara para penasun justru sebaliknya, karena menggunakan narkoba adalah perbuatan yang melanggar norma, moral dan hukum yang berlaku di masyarakat. Maka, seperti diungkapkan para informan, mereka sudah bisa mengukur penilaian dan perlakuan seperti apa yang diterapkan masyarakat pada diri mereka.

Lebih jauh dalam Teori Labeling, ada yang disebut dengan peran yang sangat khusus yang disediakan masyarakat untuk para "penyimpang" (deviant) ini, yaitu "Peran Penyimpang" atau "peran Stigmatis" atau "Stigma Sosial".

"Labeling theory concerns itself mostly not with the normal roles that define our lives, but with those very special roles that society provides for deviant behavior, called deviant roles, stigmatic roles, or social stigma."

Peran sosial cukup penting, karena dibutuhkan bagi organisasi dan memfungsikan masyarakat atau kelompok. Jadi jika individu dapat memainkan peran sosial secara positif, maka diyakini ia akan membuat fungsi organisasi atau kelompok atau bahkan masyarakat dimana ia berinteraksi akan menjadi positif. Sementara sebaliknya, jika peran sosial, Penasun misalnya, bersifat negatif, maka organisasi atau kelompok atau masyarakat akan menolak karena alih-alih memfungsikan organisasi secara positif malah menjadi negatif.

Peran sosial adalah seperangkat harapan yang kita miliki tentang perilaku, seperti dinyatakan Mead, a social role is a set of expectations we have about a behavior. Social roles are necessary for the organization and functioning of any society or group.

Jadi jelas nampak disini bahwa pada umumnya tentu masyarakat akan memiliki seperangkat harapan pada setiap individu yang menjadi anggota, sehingga masyarakat di daerah tersebut dapat berfungsi dengan baik. Ketika seorang Penasun memainkan peran sosial yang cenderung kontradiktif dengan harapan masyarakat, maka dapat menimbulkan Stigma Sosial.

Peran penyimpang dan label yang dilekatkan pada fungsi Penasun di masyarakat, adalah sebuah bentuk stigma Sosial, atau seperti diungkapkan Mead (1937), the deviant roles and the labels attached to them function as a form of social stigma.

Masyarakat menggunaka stigma sosial ini untuk 
mengontrol dan membatasi perilaku penyimpang, artinya siapapun anggota masyarakat yang masuk ke dalam proses penyimpangan maka mereka akan segera dimasukkan sebagai kelompok penyimpang, itulah sebabnya Penasun cenderung tidak memiliki teman karena anggota masyarakat memilih menghindar dan melarang anak-anak mereka untuk bergaul dengan Penasun, kecuali mereka akan dianggap sebagai kelompok Penasun juga.

"Society uses these stigmatic roles to them to control and limit deviant behavior: "If you proceed in this behavior, you will become a member of that group of people."

Peran Penyimpang ini adalah sumber adanya stereotipe negatif yang cenderung mendukung masyarakat agar tidak menyetujui perilaku ini. Deviant roles are the sources of negative stereotypes, which tend to support society's disapproval of the behavior. Walau para Penasun berkilah bahwa mereka tidak berbuat sesuatu hal yang merugikan masyarakat bahkan cenderung menarik diri dari lingkungan pergaulan, namun tetap saja, pecandu narkoba dianggap peran Penyimpang yang menjadi sumber stereotipe negatif terhadap mereka, sehingga masyarakat tetap menolak kehadirannya.

Di sisi lain, seperti diungkapkan para informan, bahwa akibat mereka menjadi pecandu narkoba maka mereka juga banyak yang positif terinfeksi virus HIVAIDS, dimana hal ini menimbulkan banyak kendala dalam kehidupan mereka, salah satunya adalah situasi yang membuat mereka berada pada kondisi serba salah. Menyampaikan secara terbuka bahwa mereka adalah ODHA akibat Penasun, mereka khawatir malah nanti dikeluarkan dari lingkungan pekerjaannya. Tetapi ketika mereka menyembunyikan status tersebut, mereka juga selalu dikejar dengan berbagai kenyataan yang menuntut mereka jujur pada masyarakat. Seperti diungkapkan informan YS,

"Saat ini saya sering dihadapkan pada situasi yang serba salah, apakah saya perlu menyampaikan pada teman-teman kantor bahwa saya ODHA atau sebaiknya saya tutupi saja. Masalahnya, kondisi fisik saya yang lemah dan rentan sakit serta keharusan minum obat ARV secara teratur dengan waktu yang harus disiplin ketat, seringkali mengundang orang bertanya sebetulnya saya sakit apa. Nah jadinya bingung kan bu?."26

Hal ini sejalan dengan apa yang dinyatakan oleh Bruce Link, bahwa stigma adalah kekuatan yang luar biasa dan gigih dalam kehidupan mereka, dan bahwa pengalaman atas penolakan masyarakat adalah sumber tekanan sosial yang sangat berat. Akibatnya, upayaupaya untuk mengatasi label ini, adalah dengan tidak menceritakan status sebenarnya kepada orang lain.

\footnotetext{
${ }^{26}$ Wawancara dengan informan YS, Oktober 2014.
}

Walaupun demikian, beberapa Penasun melawan stigma sosial ini dengan cara aktif menyampaikan informasi secara detail tentang bahaya narkoba, tentang apa itu HIV-AIDS dan ODHA dan bahkan menarik diri dari situasi stigmatisasi ini.

stigma was a powerful and persistent force in their lives, and that experiences of social rejection were a persistent source of social stress. Efforts to cope with labels, such as not telling anyone, educating people about mental distress/disorder, withdrawing from stigmatizing situations, could result in further social isolation and reinforce negative self-concepts (Bruce Link)

Selain kondisi dilematis antara open status dengan tetap menyembunyikannya, seorang informan juga secara jujur menyatakan bahwa hal yang paling menggelisahkan adalah ketika dia tidak dapat bersembunyi dari dirinya sendiri.

"Yah bu, bisa saja sih saya menyembunyikan status saya dari anak-anak, anggota keluarga atau teman kantor, tapi kan sebetulnya nurani saya tetap saja tidak bisa dibohongi, kalau saya ini ODHA." ${ }^{27}$

Seperti diungkapkan Goffman, individu yang terstigma mungkin dapat menyembunyikan atributnya dari orang lain, tetapi tidak dapat menyembunyikannya dari dirinya sendiri. "The stigmatised individual may be able to hide the discrediting attribute from others but cannot do so from him or herself" (Goffman:1967).

Akhirnya, dari uraian tentang labelling, stigma dan stigma sosial dapat dicermati dampak dari hal ini pada kehidupan sosial Penasun dalah mereka cenderung tetap menarik diri dari interaksi sosial karena berbagai pertimbangan Hal ini seolah seperti lingkaran setan, lingkaran negatif dimana perilaku menyimpang Penasun telah melahirkan labelling dan stigma sosial sebagai hukuman dari masyarakat karena dianggap melanggar norma, moral dan hukum yang berlaku, tetapi akibat dari stigma dan labelling ini membuat kelompok Penasun tidak mau berpartisipasi secara sosial dan akibatnya masyarakat sendiri menjadi dirugikan karena terjadi penurunan partisipasi sosial. Hal ini Sejalan dengan apa yang dinyatakan Goffman. "The impact of labelling and its consequences for stigmatisation can be represented as a negative feedback circle, which results in greater and greater diminution of social participation."

\section{Makna Kegiatan Promosi Kesehatan dalam meng- hapuskan Stigma}

Para Penasun memaknai upaya KPA Sumedang dalam menghapus Stigma terbagi menjadi tiga kategori, yakni bagus, cukup dan masih kurang. Di mata Penasun,

\footnotetext{
${ }^{27}$ Wawancara dengan YS, informan, Penasun yang positi HIVAIDS, tanggal 18 Oktober 2014.
} 
upaya KPA dinilai bagus karena sudah banyak membantu para Penasun menata kembali hidup mereka walaupun sudah ada yang berstatus ODHA. Selain itu, kegiatan Promosi Kesehatan KPA Sumedang sudah banyak menambah pengetahuan masyarakat tentang HIV-AIDS. Bahkan sudah makin memperjelas pengetahuan tentang proses penyebaran HIV-AIDS di kabupaten Sumedang. Namun demikian, terkait dengan Stigma yang dialami para Penasun, mereka menilai peran Promosi Kesehatan yang dilakukan KPA baru terasa cukup bahkan masih kurang. Hal ini terutama dikaitkan dengan penilaian Penasun bahwa upaya KPA baru sampai pada mengubah stigma sedikit demi sedikit atau stigma mulai berkurang. Secara konseptual, efek yang diharapkan dari suatu kegiatan komunikasi seperti promosi kesehatan selayaknya mencapai perubahan pada tiga ranah yakni, ranah kognitif, afeksi dan konatif.

Penilaian Penasun tentang bagusnya kegiatan promosi kesehatan karena sangat membantu dalam menambah pengetahuan dan memperjelas proses penyebaran HIV, termasuk pada efek komunikasi ranah kognitif. Adapun ranah afeksi dan konasi dimana diharapkan masyarakat memiliki perasaan yang sama agar bisa membuang stigma pada Penasun dinilai cukup bahkan masih kurang.Uraian analisis temuan penelitian ini, dapat disederhanakan pada bagan berikut ini,

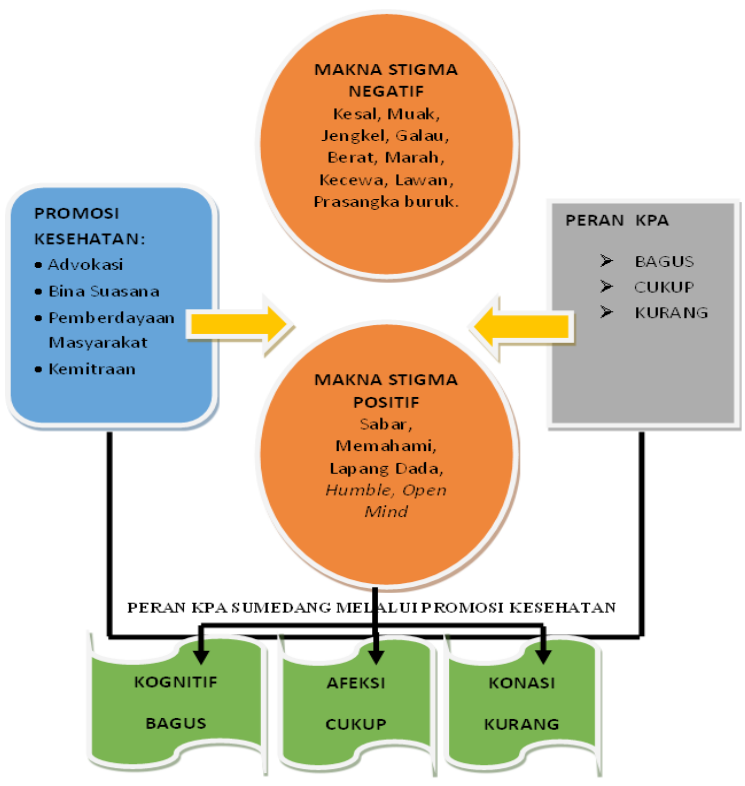

Gambar 5. Model Pemaknaan Stigma Penasun \& Peran Komisi Penanggulangan AIDS.

\section{SIMPULAN}

Kaum Pengguna Narkoba Suntik (Penasun) memaknai stigma sebagai positif dan negatif. Penasun dengan makna negatif melahirkan sikap menarik diri dari kehidupan sosial, masa bodoh, apatis, tidak peduli dan putus asa dalam menjalani sisa hidupnya, sedangkan Penasun dengan makna postif justru memberikan sisa hidupnya untuk dapat berkontribusi di masyarakat terutama dalam hal menyamapaikan informasi tentang bahaya HIV-AIDS.

Upaya KPA dalam meminimalisir penyebaran HIVAIDS melalui penggunaan jarum suntik menggunakan strategi: advokasi, bina suasana, pemberdayaan masyarakat dan kemitraan. Kendati upaya yang dilakukan sudah mengacu pada panduan dan pedoman yang diberikan oleh pemerintah, namun implementasi strategi ini di Kabupaten Sumedang masih perlu ditinjau ulang atau dievalusi secara komprehensif mengingat stigmatisasi bagi kelompom Penasun masih tetap terjadi terutama di wilayah Jatinangor.

Penasun memaknai kegiatan promosi kesehatan yang dilakukan KPA Sumedang dalam tiga kategori, yaitu bagus untuk ranah kognitif, cukup untuk ranah afeksi dan masih kurang untuk ranah konasi. Yang terakhir (ranah konasi) terkait dengan perubahan perilaku, jika kelompok penasun memaknai keiatan promosi kesehatan ini mempunyai efek hanya sebatas kognisi dan afeksi tetapi kurang dalam konasi, maka KPA Kabupaten Sumedang perlu mereinventing strategi promosi kesehatan terutama pada kelompok Penasun ini.

\section{DAFTAR PUSTAKA}

Alemu, Taddese, Sibhatu Biadgilign, Kebede Deribe \& Horacio Ruiseñor Escudero, 2013. Experience of stigma and discrimination and the implications for healthcare seeking behavior among people living with HIV/AIDS in resource-limited setting, SAHARA-J: Journal of Social Aspects of HIV/ AIDS: An Open Access Journal, downloaded by: [197.156.119.11] On: 25 July 2013, At: 09:05 Publisher: Routledge Informa Ltd Registered in England and Wales Registered Number: 1072954 Registered office: Mortimer House, 37-41 Mortimer Street, London W1T 3JH, UK.

Buku Pedoman Pencegahan \{enularan HIV-AIDS \& IMS bagi Kabupaten dan Kota se Indonesia, Departemen Kesehatan RI, 2010.

Departemen Kesehatan RI, Direktorat Jenderal Pengendalian Penyakit dan Penyehatan Lingkungan 2010

Dennis Wilcox et al, 2000, Strategi dan Taktik PR, Humanika, Salemba Grup, Jakarta.

Goffman. Erving, 1963. Stigma, Notes On Management of Spoiled Identity, London, Penguin.

Hasil Survei terhadap pelajar Mahasiswa tahun 2011, Departemen Kesehatan RI.

Mead, Goerge Herbert, 1937, Mind Self and Society, University of Chicago Publishing.Pluto Press.

McKee, Neill and Friends, 2004, Strategic Communication in the HIV/AIDS Epidemic. London. Sage Publications. 
Rodiah, Saleha et al, Jurnal Sosiohumaniora Vol 18 no 1 Maret 2016.

Rembrand Comm LLC, 2010, diunduh Maret 2010. http://www.tandfonline.com/loi/rsah20 http:// www.Wikipedia.com
WHO, Handbook on Health Inequality Monitoring with a special focus on low- and middle-income countries, WHO Library Cataloguing-in-Publication Data I.World Health Organization. ISBN 9789241548632 